\title{
'Il Sonnambulo' by Michele Carafa: A Forgotten Romantic Opera with Sleepwalking
}

\author{
Michele Augusto Riva ${ }^{a}$ Caterina Mazzocchi ${ }^{a}$ Giancarlo Cesana ${ }^{a}$ \\ Stanley Finger ${ }^{b}$

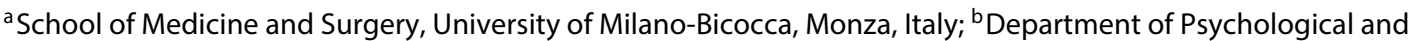 \\ Brain Sciences, and Program in History of Medicine, Washington University, St. Louis, Mo., USA
}

\section{Key Words}

Sleepwalking $\cdot$ Opera $\cdot$ Music $\cdot$ Michele Carafa .

Felice Romani $\cdot$ History

Abstract

Romantic operas provide a useful tool for historians to understand the perception of some medical disorders that existed during the nineteenth century. Somnambulism was still a mysterious condition during this time, since its pathogenesis was unknown. Hence, it comes as no surprise that somnambulism features in a number of operas, the best known of which are Verdi's 'Macbeth' and Bellini's 'La Sonnambula', both the subject of recent scholarship. Here we examine a more obscure opera in which sleepwalking is depicted. Dating from 1824, 'Il Sonnambulo' by the Italian composer Michele Carafa is based on a libretto by Felice Romani. Although it shares some features with the Verdi and Bellini operas, it also presents original elements. Our analysis of this forgotten opera supports the contention that studying operas can shed light on medical theories and practices, and on how ideas about mind and body disorders were transmitted to the laity in times past.

(c) 2016 S. Karger AG, Basel

\section{Introduction}

Somnambulism or sleepwalking has long been a subject of considerable interest, and there have been several recent articles and chapters by historians of medicine looking at past conceptions of sleepwalking, especially during the early-nineteenth century, when the hypothesized etiology of this disorder and its treatments were undergoing significant changes [1-3]. Indeed, while during the Middle Ages and Renaissance somnambulism might have been considered a curse or the overt result of some unconfessed sin, by the beginning of the Romantic period, it started to be viewed as a disorder of the mind or, in some circles and in more materialistic terms, of the brain. For example, some renowned and lesser known physicians of this time, such as Erasmus Darwin (1731-1802) and John William Polidori (1795-1821), now postulated that this nocturnal disorder could be connected to natural causes, including stress, epilepsy, and brain damage $[1,3]$.

Nonetheless, somnambulism was still being loosely defined during the early 1800s. Lacking modern technologies, and most notably the EEG, the label was based solely on observable nocturnal behaviors. Hence, it is important to remember that 'somnambulism' was more of an

\section{KARGER}

E-Mail karger@karger.com www.karger.com/ene
2016 S. Karger AG, Basel

0014-3022/16/0766-0210\$39.50/0
Michele Augusto Riva, MD, PhD

School of Medicine and Surgery University of Milano-Bicocca

via Cadore 48, IT-20900 Monza (Italy)

E-Mail michele.riva@ unimib.it 
umbrella term in times past than it is now. Indeed, physicians before and through the Romantic Era could have been, and probably were, applying this label to individuals suffering from nocturnal forms of epilepsy, hysterics, and malingerers, as well as to people who would still meet today's more stringent criteria for somnambulism $[1,4]$.

Although most of the information presented for what had previously been a loosely described disorder or group of disorders stemmed from medical texts, some authors have also examined how it had been represented in popular culture [3-6]. The importance of examining ideas related to medicine in poetry, novels, plays, and operas stems from, and supports, the belief that these vehicles might provide additional windows for understanding the state of medical knowledge at given moments in time [7]. They are able to provide details about what non-physicians might have been thinking about perplexing disorders (physical and mental) and their treatments, the kind of information they were choosing to convey, and the questions they were opting to raise to broader audiences about conditions still in need of better explanations.

Nonetheless, Romantic operas, the subject of this article, were not for everyone. Audiences during the first half of the nineteenth century were mainly composed of educated people and men and women from the higher classes of society, who were able to pay to be entertained. These paying consumers included scientists and physicians, clergy, successful businessmen, and local and regional officials. Thus, although not targeting the lower classes, Romantic operas still brought a myriad of different socioeconomic groups together.

Until now, scholars interested in the history of somnambulism have only examined 2 operas in any detail. This is understandable because both are acknowledged and frequently performed masterpieces. One is ' $\mathrm{La}$ Sonnambula,' Vincenzo Bellini's (1801-1835) opera from 1831, and the other is Giuseppe Verdi's (1813-1901) 'Macbeth' from 1847, which for all intents and purposes was faithful to William Shakespeare's (1564-1616) play from the period 1603-1606 (though not published until 1623) [3-6]. As such, these operas showed 2 different conceptions of sleepwalking. In Verdi/Shakespeare, this disorder is presented as a consequence of 'Lady' (Verdi called her by this name, not 'Lady Macbeth') murdering Macbetto's (Macbeth's) cousin Duncan, then King of Scotland, to obtain the throne. Murder was, of course, a mortal sin, and Shakespeare presents what transpired with strong metaphysical (witchcraft, religious) overtones, distancing it from secular medicine (e.g., we can even find one of the physicians in the play saying: 'This disease is beyond my practice') [4]. In contrast, Bellini provides the more enlightened idea of somnambulism as a disease, as contrasted with a divine punishment for sinning. Unlike Lady, his somnambulist is a virtuous young woman - a girl worthy of everyone's compassion, even if her strange condition is still poorly understood [4].

'La Sonnambula' and 'Macbeth', however, are not the only Italian Romantic operas featuring somnambulism. As recently pointed out by Lorusso et al. [8], somnambulism also figures prominently in Michele Carafa's (17871872) 'Il Sonnambulo' [9]. We hope to show that this now largely 'forgotten' work can also serve as a portal for looking at the status of medical knowledge and public understanding about somnambulism during the first half of the nineteenth century. In so doing, we shall compare and contrast it to the depictions of somnambulism in the masterworks just mentioned.

\section{Carafa and Romani}

'Il Sonnambulo' ('The Sleepwalker') premiered at the Teatro alla Scala in Milan on 13 November 1824 (fig. 1). Its debut featured 2 of the best operatic singers of the time: contralto Benedetta Rosmunda Pisaroni (17931872) and tenor Giovanni Battista Verger (1796-1844) [9]. Its composer, Italian aristocrat Michele Enrico Carafa di Colobrano, was born in Naples and spent his life between his hometown and Paris, where he was compelled to take refuge for political reasons. Indeed, his father forced him to take part of the Russian Campaign together with Joachim Murat (1767-1815), seriously compromising his musical career after Napoleon's fall and the Bourbon Restoration in Naples.

Carafa was a longtime friend of prolific opera composer Gioachino Rossini (1792-1868) and, upon occasion, his collaborator. He contributed to the composition of some arias in Rossini's 'Adelaide di Borgogna' (1817) and 'Mosè in Egitto' (1818); he also translated and adapted his opera 'Semiramide' for the French. His collaborations and own compositions were greatly appreciated by other composers, including Bellini and Gaetano Donizetti (1797-1848). A sensitive artist equally versed in comic and more serious genres, Carafa was recognized as an important representative of Italian music in France and as a leading figure in Parisian musical life, even though his fame was overshadowed by several other contemporaneous composers, most notably his close friend Rossini.

Felice Romani (1788-1865), the same Italian playwright and poet who would author the libretto for Bellini's 
'La Sonnambula' 7 years later, provided the libretto for Carafa's 'Il Sonnambulo.' Romani was one of finest and most prolific librettists in the nineteenth century. He wrote 'Anna Bolena' (1830) and 'L'Elisir d'Amore' (1832) for Donizetti, and 'Norma' (1831) for Bellini, who supposedly said to Romani: 'Give me good verses and I will give you good music' [10]. Romani's libretti were generally based on French literature, since he had deep interests in French culture, even though he refused to work in Paris. Other composers also based their operas on his libretti. For example, the libretto for 'Il Sonnambulo' was also used for other five operas dealing with what was essentially the same subject. They are 'Il Sonnambulo', a title used once (1830) by Luigi Ricci (1805-1859) and then 4 years later by Carlo Valentini (1790-1853), 'O Sonambulo' (1835) by Luiz Antonio Miró (1815-1835), and 'Il Fantasma' ('The Ghost'), a title selected (1842) by Salvatore Agnelli (1817-1874) and again, just a year later, by Giuseppe Persiani (1799-1869). Dating from 1824, Carafa's 'Il Sonnambulo' would seem to be the first surviving opera from the Romantic era featuring somnambulism as a central theme.

\section{‘ll Sonnambulo'}

'Il Sonnambulo' is a melodramma semiserio, meaning a piece that mixes comedic elements and a happy ending with its share of gloomy features, such as murders and clandestine plots. The story is set in Calabria, a sun-baked coastal but mountainous region forming a part of 'the boot' of Southern Italy. The libretto's foreword describes the background of the opera. Ansaldo, the Duke of Scilla, cared for his daughter, Erminia, his only heir. Ernesto, who was Ansaldo's brother, wanted his son Ermanno to marry Erminia, but Ansaldo did not trust Ernesto's intentions and was not interested in this match. Complicating matters, Erminia had fallen deeply in love with a commoner named Adolfo, but Ernesto was strongly opposed to the very idea of a marriage between a noblewoman and a simple courtier, and even suggested banning Adolfo from his brother's land. Adolfo acquiesces his own exile and leaves, not noticing that his sword had been stolen shortly before his departure. Ernesto, following the advice of his servant Ruggiero, now murdered his brother in order to make Erminia his protégée, plotting to coerce her into marrying his son. Because Ernesto had used Adolfo's sword to kill his brother, he was able to cast guilt over the innocent courtier.

\section{IL SONNAMBULO}

\section{MELODRAMMA SEMISERIO}

DA RATPRESENTARSI

\section{NELL' I. R. TEATRO ALLA SCALA}

$l$ autunno dell anno 1824.

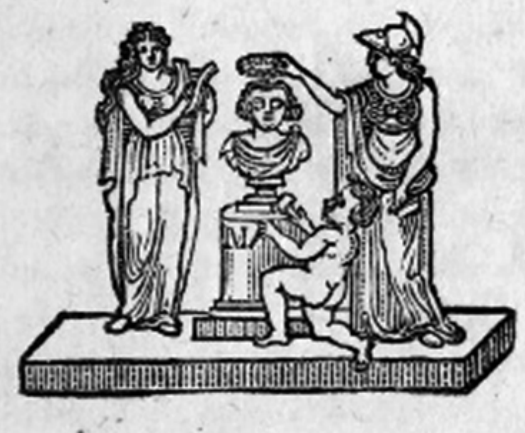

MILANO

DALLA TIPOGRAFIA DI GIACOMO PIROLA

di contro al detto I. R. Teatro:

Fig. 1. The libretto of 'Il Sonnambulo' (1824).

The opera is set one year after these events, on the very day Erminia and Ermanno were to be married. The inhabitants of Scilla and its soldiers have been frightened by what they believe was Ansaldo's ghost. The guards describe the ghost to Berto, their leader, as rather clumsy:

Sulle mura del Castello/Camminava piano piano,/Tutto avvolto in un Mantello,/Con un Lume acceso in mano. [...] Ma funebre/Vacillante, quasi scuro.../Avea chiuse le palpebre,/Lento passo e mal sicuro... (On the Castle walls,/he walked slowly,/he was covered in a cloak,/and he wielded a lighted candle./[...] But he was lugubrious,/he was unsteady, almost obscure.../He had his eyelids shut,/walked slowly and uncertainly..., Act I, scene 1) [9].

In the following scenes, audiences discover that their apparition is actually Ernesto. Oppressed by remorse, the new Duke sleepwalks around the castle every time 
the bells ring at 3 a.m., the hour he killed his brother. In the revealing Scene 3 of Act I, Ernesto enters, walking slowly ('passeggiando lentamente') with motionless eyes ('occhi immobili'). His servant Ruggiero awakens him and Ernesto complains of his miserable condition ('Oh crudo stato') and of the terrible remorse that torments him.

Adolfo now returns to the castle, still unaware that he had been formally accused of murder. He had been planning to escape with his beloved Erminia, but he is captured before he can do this. Making matters worse, Erminia believes that her lover actually murdered her father, despite his trying to prove his innocence. Because he is tormented by remorse, Ernesto inwardly hopes that Adolfo will be able to defend himself, but the other members of the Duke's Council and Ruggiero convince Ernesto to sentence the innocent courtier to death.

Adolfo's innocence is unexpectedly shown that same night. After the bells ring 3 times, Ernesto enters while sleepwalking and confesses his crime, also accusing Ruggiero of being in on the plot:

[Ruggiero] Ribaldo...sì....tu il sei... che non senti rimorso ... io fin che vivo ... ognor che suoni ... del castel la squilla ... questa terribil ora ... udrò d'Ansaldo ... l'ultimo grido ... rimombar sl cuore (Ruggiero, you are a villain, since you do not feel remorse. As long I live, every time I hear the castle's bell ring at this terrible hour, I will hear Ansaldo's last cry echo in my heart).

Ernesto suddenly wakes up, Ruggiero is arrested, and the Duke commits suicide after requesting a pardon for his son, Ermanno. Adolfo and Erminia are now free to marry and, of course, live happily together.

\section{Discussion}

'Il Sonnambulo' provides a fairly accurate description of what people could look like during a somnambulistic state. Ernesto, the sleepwalker, wanders around the castle walls with his eye closed (though he carries candles), and he is very hard to awaken. Ruggiero, in fact, has to shake him vigorously to awaken him. Furthermore, he is very confused right after he wakes up, so much so that he does not even recognize his servant. He asks him: 'Sei tu Rugger?' ('Are you Ruggiero?') [9]. Ernesto also has no memory what transpired during the night, as happens to real sleepwalkers. He becomes aware of his condition only after someone else (Ruggiero) informs and convinces him of his nightly vigils [11].

Ernesto talks while walking in his trance-like state, even confessing his crime near the end of the opera. Bellini's and Verdi's sleepwalkers, who exhibit many of the same overt traits as Ernesto, also sleep talk. Physicians today categorize sleep talking (i.e., somniloquy) as a separate disorder that occurs far more frequently than sleepwalking. Nonetheless, the newer literature also shows that people afflicted with somnambulism can have repetitive episodes of sleep talking [12]. Moreover, although somniloquy is typically devoid of emotional content, it can be associated with intense emotional stress [12], as depicted with Ernesto (Carafa), Amina (Bellini), and Lady (Verdi) in opera.

Ernesto's sleepwalking began after he committed a capital crime, from which he immediately started to experience an overwhelming sense of guilt. Indeed, one can read in the foreword to the libretto:

[Ernesto] fu preso da crudeli rimorsi: perseguitato dovunque dalla rimembranza del fratello, di giorno in preda a mille terrori, e di notte spaventato da orribili sogni, recavasi dormendo nel luogo ove commesso avea il delitto, gemendo ([Ernesto] suffered from terrible remorse. He was persecuted by the remembrance of his brother everywhere. During the day, he suffered a thousand terrors, and during the night, he was frightened by horrible nightmares. He sleepwalked to the place where he committed the crime, moaning) [9].

With Shakespeare/Verdi and with Carafa, because murder is the implied source of the lead character's mental distress, audiences are led to believe that sleepwalking is either a divine punishment (Lady) or a self-inflicted punishment (Ernesto) for a dreadful crime, which would also be a sin. Ernesto seems to understand this connection, and he continues to express his misery and remorse many times in the opera.

When associating sleepwalking with sinfulness, Carafa is more like Shakespeare/Verdi's Lady than Bellini's sleepwalker, Amina, who is a sweet peasant girl with an unblemished soul. Still, all of these operatic portrayals of somnambulism exhibit ties to times past. This is largely because all provide psychological bases for the observed sleepwalking: in 2 cases this is guilt following murder and, in the third, a misunderstanding leading to broken heart. Today, as is well known, sleepwalking is most often seen in young children, and it is regarded as a natural occurrence associated with a neurological condition (which most children will grow out of) - it is not generated by sinning or some other sort of emotional upheaval, such as a broken heart.

Retrospective diagnoses on real people can be difficult to make and support with confidence, and the problems inherent in such exercises can be multiplied when dealing with fictional characters. Still, it might be noted that 
Ernesto presents some basic characteristics of rapid eye movement (REM) parasomnia, such as REM behaviour disorder (RBD). These patients most often arise in the second half of the night (Ernesto sleepwalks at 3.00 a.m.) with sudden paroxysmal, simple or massive motor activities. Episodes of RBD are characterized by more or less purposeful gestures, sometimes associated with emotional expressions of joy, laughter, sorrow or cries. During the episode, patients may manifest behaviors somewhat or even completely different from those that might characterize their waking states. In RBD, however, the normal muscle 'atonia' of REM sleep is disrupted and patients are able to 'act out' their dreams, often exhibiting good dream recall [13]. In Carafa's description of Ernesto, these features are not reported.

Some patients with RBD may also have an overlapping syndrome containing elements of classic sleepwalking, that is, a non-REM parasomnia [14]. As with most patients who suffer from this disorder, Ernesto has no memory of the events as he calmly walks around. Whether his condition might best be thought of as an overlap syndrome of RBD and sleepwalking is intriguing, but nonetheless just more speculation about a fictional character, who might have been based on a single or multiple real cases, or perhaps just some hearsay knowledge combined with the librettist's fertile imagination.

Ernesto differs from the protagonist in Bellini's opera, in part because his nightly vigils are presented as just one aspect of his descent into madness. Notably, he also seems to suffer from paranoiac thoughts about his assassinated brother, even while awake. He is obsessed with the possibility of adding more misdeeds to his already guilty conscience, and anguished by the knowledge that he will continue to hear the clock strike 3 again, again, and again. These obsessive thoughts are accompanied by auditory and visual hallucinations. In the libretto: 'Voce ascolto in ogni lato che mi chiama fratricida...e del sangue del germano tinta io veggo ultrice mano'. And in translation: 'From all sides, I hear a voice calling me fratricide and I see the avenging hand dyed by the blood of my brother' [9].

When comparing Verdi's 'Macbeth' with Carafa's 'Il Sonnambulo', as well as with Bellini's 'La Sonnambula', it is important to recall that Verdi's opera is based on a Shakespearean play from about 1603 . As such, Lady's construction mirrors thoughts and ideas about sleepwalking dating back 2 additional centuries. In contrast, Carafa's Ernesto is an early-nineteenth-century, Romantic era construction. For this reason, if for no other, one would think that how Carafa presented his sleepwalker should, in fact, be more like how Bellini presented Amina in 'La Sonnambula' than Lady in Verdi's masterpiece. Yet Carafa's Ernesto comes across more like Verdi's Lady with her bloodied hands and guilt than Bellini's Amina, the sweet girl with an unblemished soul, who later in the opera is treated with compassion and understanding for a disorder considered no fault of her own. What is perhaps most strange about how these 2 contrasting characters are depicted is that Bellini's 'La Sonnambula' and Carafa's 'Il Sonnambulo' had the same great Italian librettist, Felice Romani.

How supernatural forces were being perceived did, however, change over time, and this too can be gleaned from these operas. In particular, ideas about witches and ghost-like phantoms wandering about at night, like those permeating Shakespeare's 'Macbeth', were thought to be unenlightened by the Romantic era. Thus, although many small town people mistake the sleepwalker for a potentially menacing phantom in Bellini's 'La Sonnambula', his librettist has the enlightened Count step forth to provide them with a more rational, naturalistic explanation for what they think they might be seeing. Similarly, while the soldiers in Carafa's 'Il Sonnambulo' seem pretty sure they have sighted a ghost, he too uses more enlightened people to provide rational explanations for this frightening phenomenon. Berto, the Captain of the Guard, for example, while unable to find a solution to the mystery, is still sure that what his men are seeing is not a ghost. This is why he asks them to investigate further, ridiculing their fear and in an almost comedic way by calling them 'sciocchi' ('fools') [9]. Ermanno, Ernesto's son, does not believe in ghost's either, and he makes the supposition that what everyone is seeing is no more than a deception aimed to frighten them. Nonetheless, and contrary to what will happen in Bellini's 'La Sonnambula', no character in Carafa's opera raises the possibility that somnambulism is, in fact, a disease - a natural medical disorder that could and should be treated with more understanding.

\section{Conclusions}

'Il Sonnambulo' by Michele Carafa shares many features with both 'La Sonnambula' by Vincenzo Bellini and 'Macbeth' by Giuseppe Verdi. Like Bellini's masterpiece, it is an opera semiseria. Also like the Bellini opera, its libretto was written by Romani during the Romantic Era, when witchcraft and supernatural events were being attributed to superstitions and misunderstandings, at least by the educated and more acculturated elements 
of society [15]. Yet on closer examination, Ernesto's sleepwalking disorder is more like Lady's, most notably in sharing the same psychogenic cause: a guilty conscience stemming from a violent crime. This feature, and even the guiltless Amina's psychogenically caused sleepwalking, show us that during the opening decades of the nineteenth century the etiology of sleepwalking was still unknown and quite mysterious. Although enlightened physicians and educated people were now discarding supernatural beliefs for more rational explanations of what they were witnessing, most people were probably not ready to envision it as a disease that could afflict anyone.

There are, however, some notable features in 'Il Sonnambulo' that are not found in Bellini's or in Verdi's operas, and they too should not escape our attention. First, Carafa's sleepwalker was an adult man. This is a departure from the then-held belief that somnambulism is far more common among women than men, because of weak female constitutions, frail nerves, and the unnatural stresses of urbanization [6]. This sort of thinking might have entered into Carafa's decision to emphasize his sleepwalker's guilty conscience, as opposed to a constitutional weakness. Second, despite sharing the same librettist, Carafa's sleepwalker could be awakened without serious risk, in a very public way dispelling the old myth that awakening a sleepwalker can be dangerous and even fatal. This fear can be found in Shakespeare's play and in Verdi's production of 'Macbetto', and it can, in fact, still be found in Bellini's 'La Sonnambula', where we find Amina's lover, the rustic Rodolfo saying: 'Silenzio: un sol passo, un sol grido l'uccide', meaning 'Silence! A single step, a shout can kill her' [16]. A third significant difference is that the sleepwalking in 'Il Sonnambulo' is triggered externally (by 3 clock bells at the time his crime had been committed). In both Verdi's and Bellini's opera's, the sleepwalking is not triggered by some sound during the night: it just manifests itself like a dream.

Whether Carafa and his librettist might have been influenced by certain theories about 'lunatism' and 'artificial sleepwalking', notably the ideas of Franz Anton Mesmer (1734-1815) and Armand M.J. de Chastenet (Marquis de Puységur; 1751-1825), which were widespread during this era, is not at all clear $[3,17]$. Despite such gaps, an analysis of 'Il Sonnambulo' and other operas can still serve as valuable resources for understanding mental (and physical) disorders during times past, especially as conveyed from and to non-physicians. Operas are among the more overlooked, non-medical resources that can provide additional means for understanding medicine and medical knowledge in the past, while providing unique perspectives for informative future research.

\section{Disclosure Statement}

The authors certify that there is no actual or potential conflict of interest in relation to this article.

\section{References}

1 Finger S, Stiles A: Lord Byron's physician: John William Polidori on somnambulism. Prog Brain Res 2013;205:131-147.

2 Wienholt A: Seven Lectures on Somnambulism. London, Longman, Brown, Green, and Longmans, 1845.

3 Umanath S, Sarezky D, Finger S: Sleepwalking through history: medicine, arts, and courts of law. J Hist Neurosci 2011;20:253-257.

4 Riva MA, Tremolizzo L: History - features, factors, and characteristics of parasomnias; in Kushida CA (ed): The Encyclopedia of Sleep. Waltham, Academic Press, 2013, vol 4, pp 152-156.

5 Riva MA, Sironi VA, Tremolizzo L, Lombardi C, De Vito G, Ferrarese C, Cesana G: Sleepwalking in Italian operas: a window on popular and scientific knowledge on sleep disorders in the 19th century. Eur Neurol 2010;63:116-121.

6 Finger S, Sironi VA, Riva MA: Somnambulism in Verdi's Macbeth and Bellini's La Son- nambula: opera, sleepwalking, and medicine. Prog Brain Res 2015;216:357-388.

7 Riva MA, Bellani I, Turato M, Cesana G: Physicians and alternative medicines in 'The Barber of Seville' by Gioachino Rossini: a bicentennial debate. Eur J Intern Med 2015;26:757-758.

8 Lorusso L, Franchini AF, Porro A: Opera and neuroscience. Prog Brain Res 2015;216:389409.

9 Romani F: Il Sonnambulo: Melodramma Semiserio. Milan, Tipografia Giacomo Pirola, 1824.

10 Raeburn M, Kendall A: Heritage of Music: The Romantic Era, Volume 2. Oxford, Oxford University Press, 1989, p 240.

11 Jain V: Sleepwalking; in Kushida CA (ed): The Encyclopedia of Sleep. Waltham, Academic Press, 2013, vol 4, p 202.

12 Pollak CP, Thorpy MJ, Yager J: The Encyclopedia of Sleep and Sleep Disorders, ed 3. New York, Facts on File Incoporated, 2009, p 230.
13 Avidan AY: Parasomnias and movement disorders of sleep. Semin Neurol 2009;29:372392.

14 Schenck CH, Boyd JL, Mahowald MW: A parasomnia overlap disorder involving sleepwalking, sleep terrors, and REM sleep behavior disorder in 33 polysomnographically confirmed cases. Sleep 1997;20:972981.

15 Riva MA, Scordo F, Turato M, Messina G, Cesana G: The web of Penelope. Regulating women's night work: an unfinished job? Vesalius 2015;21:14-22.

16 Romani F: La Sonnambula: Melodramma in Due Atti. Testi a Cura di Eduardo Rescigno. Milan, Ricordi, 1990.

17 Riva MA, Tremolizzo L, Spicci M, Ferrarese C, De Vito G, Cesana GC, Sironi VA: The disease of the moon: the linguistic and pathological evolution of the English term 'lunatic'. J Hist Neurosci 2011;20:65-73. 